\title{
Assessment of Physicochemical Parameters and Phytoplankton of Eme River, Umuahia, Southeast Nigeria
}

\author{
Emeka Donald Anyanwu ${ }^{1}$, Onyinyechi Gladys Adetunji ${ }^{1}$, Solomon Nnanna Umeham ${ }^{2}$ \\ ${ }^{I}$ Department of Zoology and Environmental Biology, Michael Okpara University of Agriculture, Umudike, \\ Nigeria \\ ${ }^{2}$ Department of Animal and Environmental Biology, Abia State University, Uturu, Nigeria \\ *Corresponding Author: ed.anyanwu@mouau.edu.ng
}

\begin{tabular}{|c|c|c|c|}
\hline Recei & Received in revised form & Accepted & ble online \\
\hline 26 May 2021 & 24 August 2021 & 04 September 2021 & 25 September 2021 \\
\hline
\end{tabular}

\begin{abstract}
Aquatic ecosystems respond differently to diverse anthropogenic activities in their watersheds. Phytoplankton is sensitive to their environment and is used to monitor anthropogenic impacts. A study was carried out in a South-eastern Nigerian River between December 2017 and November 2018 in 6 stations; to assess the phytoplankton community, water quality, and anthropogenic impacts. Sand mining was a major activity in the river among others. The phytoplankton was sampled with the filtration method while water was collected and analyzed using standard methods. A total of 36 phytoplankton species were recorded with Chlorophyceae being the most abundant group. The most abundant species - Melosira granulata is a pollution indicator. The water quality and phytoplankton structure showed that the water was tending towards eutrophication. This is attributed to the observed anthropogenic activities and cumulative impacts of all the activities in the watershed. The impact of sand mining activities was observed more in the downstream stations $(4-6)$ while perturbation from swimming children and related activities was observed in station 1 . The community structure reflected the impacts of the activities while CCA showed the major water quality parameters that influenced the phytoplankton community structure. Keywords: anthropogenic, bioindicator, diversity, sand mining, water quality
\end{abstract}

Abstrak: Ekosistem akuatik merespons secara berbeda terhadap beragam aktivitas antropogenik di DASnya. Fitoplankton sensitif terhadap lingkungannya dan digunakan untuk memantau dampak antropogenik. Sebuah penelitian dilakukan di Sungai Nigeria Tenggara antara Desember 2017 dan November 2018 di 6 stasiun; untuk menilai komunitas fitoplankton, kualitas air dan dampak antropogenik. Kegiatan penambangan pasir merupakan salah satu kegiatan utama di sungai. Fitoplankton diambil sampelnya dengan metode filtrasi sedangkan air dikumpulkan dan dianalisis menggunakan metode standar. Sebanyak 36 spesies fitoplankton tercatat dengan Chlorophyceae sebagai kelompok yang paling melimpah. Spesies paling melimpah - Melosira granulata adalah indikator pencemaran. Kualitas air dan struktur fitoplankton menunjukkan bahwa air cenderung eutrofikasi. Hal ini disebabkan oleh aktivitas antropogenik yang diamati dan dampak kumulatif dari semua aktivitas di DAS. Dampak kegiatan penambangan pasir lebih banyak diamati di stasiun hilir (4 - 6) sedangkan gangguan dari anak-anak berenang dan kegiatan terkait diamati di stasiun 1. Struktur komunitas mencerminkan dampak kegiatan sementara CCA menunjukkan parameter kualitas air utama yang mempengaruhi struktur komunitas fitoplankton.

Kata kunci: antropogenik, bioindikator, keanekaragaman, kualitas air, penambangan pasir

\section{Introduction}

Freshwater bodies all over the world are under great pressure from anthropogenic activities in and around the water bodies [1][2]. Physicochemical parameters give an insight into water chemistry and quality, which alone does not give a clear picture of the ecological condition of the water body; since they cannot be properly integrated with the ecological variables [3]. Water bodies provide habitats to a range of organisms; as a result, the effect and response to environmental stressors may vary from producers to consumers [4]. Aquatic biota living in freshwaters are widely used to monitor the levels of pollution worldwide [5][7]. Among the aquatic biota used in freshwater monitoring, phytoplankton is the primary producer and the base for aquatic food webs that sustain freshwater ecosystem stability and function [8].

Phytoplankton is widespread in freshwater bodies, such as streams, lakes, and rivers. They are relatively unnoticed except in bloom conditions but play a major role in terms of ecology and in relation to human use of freshwater [9]. Phytoplankton is microplant organisms without distinct roots, stems, and leaves [10]. Phytoplankton species composition, abundance, and diversity vary with environmental conditions such as nutrients level, temperature, light and predator pressure, etc.

The phytoplankton community plays a key role in aquatic ecosystems as bioindicator and primary producers; providing for carbon fixation, oxygen, and 
food production [11]. Phytoplankton species are able to survive and develop in diverse aquatic habitats but each species is restricted to a defined niche based on their physiological requirements and environmental limitations [12]. The presence or absence of the indicator organisms can reveal aquatic environmental conditions. Phytoplankton productivity and biomass in freshwater ecosystems are significantly increased through anthropogenic nutrient enrichment [13][14]. Understanding the effects of environmental parameters on phytoplankton communities is important to assess the effects of anthropogenic impacts [15].

A number of anthropogenic activities were observed in the Eme River, of which illegal and indiscriminate sand mining was the major one. The objective of this study was therefore to assess some physicochemical parameters and phytoplankton diversity in relation to anthropogenic activities.

\section{Material and Methods}

\subsection{Study Area}

Eme River originated from Uzoakoli in Abia State, Nigeria, and flows through many communities before discharging into Imo River at Onuimo. The studied area section lies between latitude $5^{\circ} 38^{\prime}$ and $5^{\circ} 37^{\prime} \mathrm{N}$ and Longitude $7^{\circ} 25^{\prime}$ and $7^{\circ} 26^{\prime} \mathrm{E}$; about $3.25 \mathrm{~km}$ in length, from Ofeme to Umudiawa in Umuahia, Abia State (Figure 1). Falling within the sub-equatorial zone, mean annual rainfall of about $4000 \mathrm{~mm}$ per annum. It is also characterized by high relative humidity of over $70 \%$ and high temperature of about $29-31^{\circ} \mathrm{C}$. The study area is also characterized by two seasons - wet (June to November) and dry (December to May) and double maxima rainfall peaks in July and September; a short period of dryness (August break) is experienced between the peaks. Based on accessibility and anthropogenic activities, the river was divided into six stations.

All the stations were within the dredged section except station 1. The control station (Station 1) was upstream and located within the Ofeme community at Mbato, laundry and extraction of drinking water were observed especially during the dry season. Also due to close proximity, easy accessibility, and low water depths, a large number of children are usually observed swimming during the dry season up to early rains. The substrate is mixed. Station 2 was located at the out sketch of the community (Eme- Ihite), about $1.84 \mathrm{~km}$ downstream of Station 1. Laundry, swimming, and extraction of drinking water were observed in the dry season while minimal sand mining was observed in the wet season. The substrate is mixture of sand and stones. Station 3, also located in Eme - Ihite, close to the expressway, about $419.67 \mathrm{~m}$ downstream of Station 2. Periodic boat movements were the only activities observed. The substrate is made up of large clayey boulders. Station 4, located in Umudiawa Community across the expressway, about $490.26 \mathrm{~m}$ downstream of Station 3. An intensive sand mining and two sand landing sites were located upstream to Station 4. The substrate was sandy. Station 5 was about $200.22 \mathrm{~m}$ downstream of Station 4; within Umudiawa Community. The substrate was sandy supporting sand mining activities. Station 6 was about $300.14 \mathrm{~m}$ downstream of Station 5; also within Umudiawa Community. Sand mining occurred in the water channel and around the shores. The substrate was sandy.

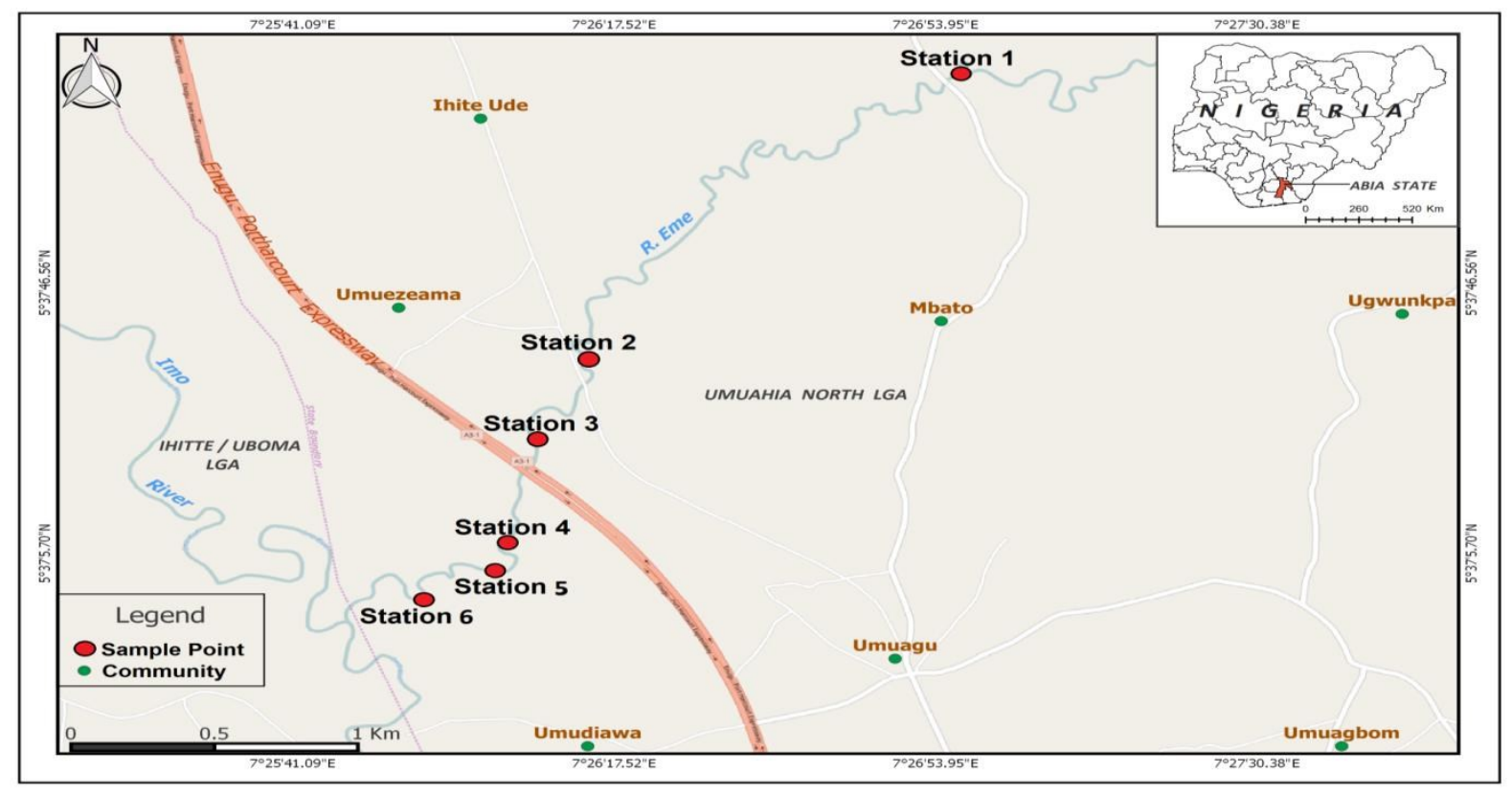

Figure 1: Map of Umuahia, Abia State, Nigeria showing the sampling Stations of Eme River 


\subsection{Methods}

\subsubsection{Sample collection and analysis}

\subsubsection{Water samples}

Water samples were collected monthly between December 2017 and November 2018. One litre water sampler was used and samples were transferred into sterilized 1 litre plastic bottles and taken to the laboratory for analysis. In-situ determinations were carried out for Water Temperature, Flow Velocity, Turbidity, $\mathrm{pH}$, and Total Dissolved Solids while Dissolved Oxygen, Biochemical Oxygen Demand, Nitrate, and Phosphate were determined in the laboratory using standards methods by [16].

\subsubsection{Phytoplankton samples}

Phytoplankton samples were collected from undisturbed areas of the river monthly as the water samples. The sampling was carried out using the filtration method. A composite sample of 100 litres of water was filtered through $55 \mu \mathrm{m}$ Hydro-Bios plankton net. The net content was washed out into plankton bottles of $250 \mathrm{ml}$ size and preserved in $4 \%$ formalin solution. In the laboratory, one $\mathrm{ml}$ of the preserved sample was taken as a sub-sample using a pipette. The collected sample was put on the Sedgwick-rafter counting chamber and viewed under a light binocular microscope (Nikon 400 binocular microscope) using a low magnification of $\mathrm{x} 10$. Phytoplankton was sorted into different groups and the cells per $\mathrm{ml}$ were counted. Identification work was done using key literature by [10] and [17]. The identification was made to the lowest practicable taxonomic.

\subsection{Data Analysis}

The results were summarized with Microsoft Excel while one-way ANOVA was used to test for statistical differences among the stations and Tukey's pairwise comparisons test was used to locate the source of the significant difference $(\mathrm{P}<0.05)$. Margalef (D), Shannon-Wiener (H), and Evenness (E) indices were used to determine the community structures of the phytoplankton while Canonical correspondence analysis (CCA) was used to evaluate relationships between the phytoplankton groups and environmental variables.

\section{Results and Discussion}

\subsection{Water Quality}

The physicochemical parameters studied are presented in Table 1. Surface water temperature ranged between $22.0^{\circ} \mathrm{C}$ and $28.5^{\circ} \mathrm{C}$. The surface water temperatures were within acceptable limits; influenced by season and sampling times. The lowest value was recorded in station 1 in May 2018 after an early rain while the highest was recorded in station 6 in April 2018 during the dry season. Air temperatures have been reported to strongly influence surface water temperatures [18]. Water temperature is an important factor in biotic and abiotic processes; affecting the amount of dissolved matter, organic/inorganic pollutants, nutrients, micro bacterial concentrations, and the behavior of organisms in the aquatic environment [19].

Flow velocity values were moderate; ranging between 0.21 and $0.85 \mathrm{~m} / \mathrm{s}$. The lowest flow velocity was recorded in station 1 in April 2018 while the highest was recorded in station 3 in December 2017. Stations 2 and 3 were significantly higher $(\mathrm{F}=31.59 ; \quad P<0.05)$ than the other stations. Flow velocity can significantly affect the ability of a waterbody to assimilate and transport pollutants [20]. It can also affect the composition, abundance, and distribution of aquatic biota. Increased river discharge and flow velocity, especially during the wet season, has been reported to be responsible for low species composition and abundance in rivers due to low time of residency [21-23]. This study was different; the highest phytoplankton abundance was recorded in Station 3 with high flow velocities. This could be as a result of little or no human activities observed in the station. CCA showed that flow velocity was a strong negative factor especially in Station 3.

Turbidity ranged between 0.5 and 9.4 NTU. The lowest and highest values were recorded in station 4 in March and February 2018 respectively. The standard limit (5 NTU) was exceeded by some values recorded in all the stations especially between December 2017 and March 2018; attributable to the cumulative effect of receding flood and anthropogenic activities. Turbidity in Station 1 could have been influenced by a large number of children swimming and other activities (bathing, washing, and extraction of water for drinking) observed during the dry season. However, the effect of sand mining activities which increased with the rains could be responsible for the relatively higher values recorded in Stations 4 - 6 between May and November 2018 [24][25]. This was more significant in Station 4 which was immediately downstream of sand mining and landing sites and gradually reduced further downstream [26][27]. The negative effect of turbidity in station 4 was highlighted by CCA. High turbidity levels affect aquatic lives [28][29]. All the $\mathrm{pH}$ values recorded were acidic (4.3 - 6.3); lower than the acceptable limits $(6.5-8.5)$. The lowest and highest $\mathrm{pH}$ were recorded in stations 2 (June 2018) and 1 (September 2018) respectively. Geogenic [30] and anthropogenic influences [31-32] could be responsible for the low $\mathrm{pH}$.. It has been reported that sand mining lowers the $\mathrm{pH}$ of water bodies [27]. Extremes of $\mathrm{pH}$ are detrimental to most aquatic organisms. Aquatic organisms are extreme sensitivity to $\mathrm{pH}$ levels below 5; death could occur at such low $\mathrm{pH}$ values [29]. CCA showed a strong negative influence of $\mathrm{pH}$ on phytoplankton. .The electrical conductivity (EC) values ranged 
between 45.2 and $168.4 \mu \mathrm{S} / \mathrm{cm}$. The lowest and highest values were recorded in stations 2 and 5 in March and January 2018 respectively. The downstream stations $(4-6)$ were significantly higher $(\mathrm{F}=29.59 ; p<0.05)$ than the upstream stations $(1-3)$. This could be a result of sand mining activities. Increased levels of EC in surface water have been associated with sand mining activities
[31][33] and increasing EC usually points to increasing water pollution [34]. The EC values recorded in Station 1 were relatively higher compared to Stations 2 and 3; The effect of the large number of children swimming observed during sampling in the dry season and allochthonous input from increased runoff during the wet season could be responsible.

Table 1: Summary of Physico-chemical Parameters of Eme River, Umuahia, Abia State.

\begin{tabular}{|c|c|c|c|c|c|c|c|c|}
\hline Parameter & $\begin{array}{c}\text { Stn } 1 \\
\mathrm{X} \pm \mathrm{SEM}\end{array}$ & $\begin{array}{c}\text { Stn } 2 \\
\mathrm{X} \pm \mathrm{SEM}\end{array}$ & $\begin{array}{c}\text { Stn } 3 \\
\mathrm{X} \pm \mathrm{SEM}\end{array}$ & $\begin{array}{c}\text { Stn } 4 \\
\mathrm{X} \pm \mathrm{SEM}\end{array}$ & $\begin{array}{c}\text { Stn } 5 \\
\mathrm{X} \pm \text { SEM }\end{array}$ & $\begin{array}{c}\text { Stn } 6 \\
\mathrm{X} \pm \text { SEM }\end{array}$ & $\begin{array}{c}\mathrm{P}- \\
\text { value }\end{array}$ & FMEnv. \\
\hline $\begin{array}{l}\text { Water } \\
\text { Temperature } \\
\left({ }^{\circ} \mathrm{C}\right)\end{array}$ & $\begin{array}{c}24.8 \pm 0.59 \\
(22.0-28.0)\end{array}$ & $\begin{array}{c}24.9 \pm 0.54 \\
(22.5-28.2)\end{array}$ & $\begin{array}{c}24.8 \pm 0.53 \\
(23.0-28.2)\end{array}$ & $\begin{array}{c}24.9 \pm 0.51 \\
(23.2-28.4)\end{array}$ & $\begin{array}{c}24.4 \pm 0.53 \\
(23.0-28.3)\end{array}$ & $\begin{array}{c}24.8 \pm 0.53 \\
(22.9-28.5)\end{array}$ & $\mathrm{P}>0.05$ & $<40$ \\
\hline $\begin{array}{l}\text { Turbidity } \\
\text { (NTU) }\end{array}$ & $\begin{array}{l}4.2 \pm 0.61 \\
(1.5-9.3)\end{array}$ & $\begin{array}{l}3.5 \pm 0.52 \\
(1.3-8.1)\end{array}$ & $\begin{array}{l}3.0 \pm 0.48 \\
(0.6-5.4)\end{array}$ & $\begin{array}{l}5.0 \pm 0.72 \\
(0.5-9.4)\end{array}$ & $\begin{array}{l}3.9 \pm 0.61 \\
(0.7-7.8)\end{array}$ & $\begin{array}{l}4.1 \pm 0.56 \\
(0.9-6.9)\end{array}$ & $\mathrm{P}>0.05$ & 5 \\
\hline $\begin{array}{l}\text { Flow Velocity } \\
(\mathrm{m} / \mathrm{s})\end{array}$ & $\begin{array}{l}0.35 \pm 0.02^{\mathrm{a}} \\
(0.21-0.49)\end{array}$ & $\begin{array}{l}0.56 \pm 0.04^{b} \\
(0.37-0.80)\end{array}$ & $\begin{array}{l}0.71 \pm 0.02^{\mathrm{c}} \\
(0.63-0.85)\end{array}$ & $\begin{array}{l}0.36 \pm 0.02^{\mathrm{a}} \\
(0.24-0.46)\end{array}$ & $\begin{array}{l}0.37 \pm 0.02^{\mathrm{a}} \\
(0.28-0.50)\end{array}$ & $\begin{array}{c}0.45 \pm 0.0^{\mathrm{a}} \\
(0.26-0.58)\end{array}$ & $\mathrm{P}<0.05$ & - \\
\hline $\begin{array}{l}\mathrm{pH} \\
\text { (unit) }\end{array}$ & $\begin{array}{l}5.69 \pm 0.11 \\
(5.0-6.3)\end{array}$ & $\begin{array}{l}5.43 \pm 0.13 \\
(4.3-5.9)\end{array}$ & $\begin{array}{l}5.42 \pm 0.10 \\
(4.9-6.1)\end{array}$ & $\begin{array}{l}5.53 \pm 0.10 \\
(5.0-6.1)\end{array}$ & $\begin{array}{l}5.49 \pm 0.10 \\
(5.1-6.2)\end{array}$ & $\begin{array}{l}5.55 \pm 0.10 \\
(5.1-6.1)\end{array}$ & $\mathrm{P}>0.05$ & $\begin{array}{l}6.5- \\
8.5\end{array}$ \\
\hline $\begin{array}{l}\text { Electrical } \\
\text { Conductivity } \\
(\mu \mathrm{S} / \mathrm{cm})\end{array}$ & $\begin{array}{c}86.0 \pm 4.40^{\mathrm{a}} \\
(55.6- \\
115.8)\end{array}$ & $\begin{array}{l}71.3 \pm 4.43^{\mathrm{a}} \\
(45.2-95.4)\end{array}$ & $\begin{array}{l}65.7 \pm 3.50^{\mathrm{a}} \\
(49.6-88.7)\end{array}$ & $\begin{array}{c}130.4 \pm 5.86^{\mathrm{b}} \\
(90.3- \\
160.2)\end{array}$ & $\begin{array}{c}115.4 \pm 6.04^{\mathrm{b}} \\
(88.5- \\
168.4)\end{array}$ & $\begin{array}{c}119.6 \pm 5.38^{b} \\
(87.1- \\
148.4)\end{array}$ & $\mathrm{P}<0.05$ & - \\
\hline $\begin{array}{l}\text { Dissolved } \\
\text { Oxygen (mg/l) }\end{array}$ & $\begin{array}{l}3.7 \pm 0.38 \\
(2.3-5.7)\end{array}$ & $\begin{array}{l}3.6 \pm 0.34 \\
(2.2-5.9)\end{array}$ & $\begin{array}{l}3.7 \pm 0.40 \\
(1.8-6.1)\end{array}$ & $\begin{array}{l}3.9 \pm 0.46 \\
(1.6-6.1)\end{array}$ & $\begin{array}{l}3.6 \pm 0.37 \\
(2.0-5.5)\end{array}$ & $\begin{array}{l}3.8 \pm 0.42 \\
(1.8-5.8)\end{array}$ & $\mathrm{P}>0.05$ & 6 \\
\hline $\begin{array}{l}\text { Biochemical } \\
\text { Oxygen } \\
\text { Demand (mg/l) }\end{array}$ & $\begin{array}{c}1.7 \pm 0.14^{\mathrm{ab}} \\
(1.0-2.5)\end{array}$ & $\begin{array}{l}1.5 \pm 0.08^{b} \\
(1.1-1.9)\end{array}$ & $\begin{array}{l}1.7 \pm 0.12^{b} \\
(1.1-2.4)\end{array}$ & $\begin{array}{c}2.6 \pm 0.37^{\mathrm{ac}} \\
(0.8-4.3)\end{array}$ & $\begin{array}{c}1.9 \pm 0.20^{\mathrm{ab}} \\
(1.0-3.2)\end{array}$ & $\begin{array}{c}2.1 \pm 0.25^{\mathrm{ab}} \\
(0.9-3.9)\end{array}$ & $\mathrm{P}<0.05$ & 3 \\
\hline Nitrate $(\mathrm{mg} / \mathrm{l})$ & $\begin{array}{c}2.9 \pm 0.30^{b} \\
(1.8-4.9)\end{array}$ & $\begin{array}{c}2.2 \pm 0.17^{\mathrm{b}} \\
(1.3-3.2)\end{array}$ & $\begin{array}{l}1.6 \pm 0.12^{\mathrm{a}} \\
(1.1-2.4)\end{array}$ & $\begin{array}{l}4.5 \pm 0.20^{\mathrm{c}} \\
(3.4-5.6)\end{array}$ & $\begin{array}{c}2.6 \pm 0.37^{\mathrm{ab}} \\
(1.2-5.3)\end{array}$ & $\begin{array}{c}2.9 \pm 0.27^{\mathrm{b}} \\
(1.9-5.2)\end{array}$ & $\mathrm{P}<0.05$ & 9.1 \\
\hline $\begin{array}{l}\text { Phosphate } \\
(\mathrm{mg} / \mathrm{l})\end{array}$ & $\begin{array}{c}1.3 \pm 0.08^{\mathrm{a}} \\
(1.0-1.9)\end{array}$ & $\begin{array}{c}0.8 \pm 0.10^{\mathrm{a}} \\
(0.5-1.7)\end{array}$ & $\begin{array}{c}0.7 \pm 0.07^{\mathrm{a}} \\
(0.4-1.2)\end{array}$ & $\begin{array}{c}3.4 \pm 0.18^{b} \\
(2.8-4.6)\end{array}$ & $\begin{array}{c}2.8 \pm 0.22^{b c} \\
(1.9-4.3)\end{array}$ & $\begin{array}{c}2.9 \pm 0.21^{b c} \\
(2.0-4.5)\end{array}$ & $\mathrm{P}<0.05$ & 3.5 \\
\hline
\end{tabular}

Remarks: $a, b, c, d, e=$ Means with different superscripts across the rows are significantly different at $\mathrm{p}<0.05$; SEM= Standard. Error of Mean; FMEnv. National Environmental (Surface and Groundwater Quality Control) Regulations (2011).

The dissolved oxygen (DO) values ranged from 1.6 to $6.1 \mathrm{mg} / \mathrm{L}$. Only two of the values recorded exceeded the acceptable limit $(6 \mathrm{mg} / \mathrm{L})$ set by [35] while all the rest were below. The lowest value was recorded in Station 4 (November 2018) while the highest was recorded in Stations 3 (January 2018) and 4 (February 2018). Most of the Dissolved Oxygen values were lower than the acceptable limit especially in station 4 where the effects of sand mining were higher. The addition of nutrients, changing of flow of water, raising the water temperature and the addition of chemicals are some of the consequences of sand mining activities that could contribute to oxygen depletion in water [36]. Dissolved oxygen (DO) has been described as one of the major parameters used in the evaluation of water quality [37] and the level is necessary to support aquatic biodiversity. [38] reported that dissolved oxygen is essential to support aquatic life and good fish production at levels $>5 \mathrm{mg} / \mathrm{L}$.

Biochemical Oxygen Demand (BOD) is an important parameter of water indicating the health and self-purification status of freshwater bodies. The values ranged between 0.8 and $4.3 \mathrm{mg} / \mathrm{L}$ with the lowest and highest values recorded in November 2018 and February 2018 respectively in station 4. The acceptable limit of $3 \mathrm{mg} / \mathrm{L}$ was exceeded by some of the values especially in the downstream Stations (4-6), which could be as a result of sand mining activities. Station 4 was significantly higher than stations 2 and $3(\mathrm{~F}=3.43 ; p<0.05)$. Sand mining activities exacerbate the release and circulation of organic matter from the sediments into the water column which can increase the BOD levels [31]. High BOD levels are capable of negatively affecting dissolved oxygen contents and adversely 
affecting the aquatic biota; therefore, it is a pointer to potential pollution problems [39].

Nitrate, a common form of nitrogen occurs naturally in many environments at moderate levels [40]. The values were all within the acceptable limit and ranged from 1.1 to $5.6 \mathrm{mg} / \mathrm{L}$; though higher values were recorded in Stations $4-6$ pointing to the effects of sand mining. Station 4 was significantly $(\mathrm{F}=14.62 ; p<0.05)$ higher than the other stations. The lowest value was recorded in station 3 (June 2018) while the highest was recorded in station 4 (February 2018). In Okoro Nsit stream South-south Nigeria; subjected to intense sand mining activities, [31] recorded higher values of 10.7 to $12.4 \mathrm{mg} / \mathrm{l}$. The relatively higher values recorded in Station 1 compared to Stations 2 and 3 could be from the effect of the large number of children swimming during the dry season and increased allochthonous input during the wet season. Naturally, nitrate is often between 0.01 and 3.0 $\mathrm{mg} / \mathrm{L}$; consequently, water with values higher than $5.0 \mathrm{mg} / \mathrm{L}$ is considered poor [41]. Nitrates have negative impact on the environment; noted for contamination of ground and surface waters due to their high solubility [40].

The nutrient levels and eutrophication of the river system can be identified by the concentrations of phosphate in the river [42]. Phosphate values ranged between 0.4 and $4.6 \mathrm{mg} / \mathrm{L}$. Stations $4-6$ recorded values that exceeded the acceptable limit and were significantly different $(\mathrm{F}=56.71 ; p<0.05)$ from stations $1-3$; attributable to sand mining. A range of 2.5 to $3.6 \mathrm{mg} / 1$ in Okoro Nsit stream in Akwa Ibom State, Nigeria [31]. Relatively higher values were also recorded in Station 1 attributed to perturbation from the large number of children swimming during the dry season and increased allochthonous input during the wet season. The values of 0.005 to $0.020 \mathrm{mg} / \mathrm{L}$ as normal in most natural surface waters while high concentrations can point to pollution and are mainly responsible for eutrophication [20]. The growth of algae and other photosynthetic aquatic life is stimulated by nutrients such as nitrogen and phosphates compounds in water [43].

\subsection{Phytoplankton Composition, Abundance and Distribution}

The composition and abundance of plankton of the water body is a clear indication of the health status of the water body [44]. The species composition, abundance, and distribution are presented in Table 2. A total of 5213 phytoplankton individuals was recorded, out of which the most abundant group was Chlorophyceae (1776 or $34.1 \%$ ), followed by Bacillariophyceae (1234 or $23.7 \%$ ). Other phytoplankton taxa recorded were Cyanophyceae (838 or 16.1\%), Euglenophyceae
(835 or $16.0 \%$ ), and Pyrrophyceae (530 or $10.2 \%$ ). One- way ANOVA showed that Cyanophyceae, Euglenophyceae, and Pyrrophyceae were significantly $(\mathrm{F}=18.0, \quad p<0.05)$ lower than Chlorophyceae and Bacillariophyceae in terms of abundance.

The phytoplankton was dominated by Chlorophyceae followed by Bacillariophyceae as reported by [45] and [46]. Chlorophyceae was also reported as the dominant in Odot Stream by [47] while the dominance of Bacillariophyceae was reported in Ikpa River by [23], Idumayo River by [4] both in Southeast Nigeria, River Kaduna in North Central Nigeria by [48] and Orashi River, Southsouth Nigeria by [49]. The growth and development of Chlorophyceae are controlled by parameters like transparency, water temperature, dissolved oxygen, $\mathrm{pH}$, and nutrients [50][52] while low levels of DO and high BOD, nitrate, and phosphate, favor the growth of diatoms [45]. High abundance of diatoms is attributed to high levels of silicates in the water, resulting from sand mining activities [23] and also suggests perturbation and organic pollution [49].

The number of taxa (species) recorded was 36 in all the stations except station 6 with 35 . They are lower than 41 species recorded [53], 80 species [4], and 102 species by [54] which could be attributed to anthropogenic and seasonal impacts. However, they are higher than 24 species recorded [48][49] and 26 species [46]. The composition of the phytoplankton was dominated cosmopolitan and pollution tolerant species [4][45][46][49][55]. The most abundant phytoplankton species recorded was Melosira granulata (Bacillariophyceae) with 190 individuals (3.64 \% of the total phytoplankton abundance), followed by Planktosphaeria gelatinosa (Chlorophyceae) with 180 individuals/L (3.45\% of the total phytoplankton abundance) and the least was Peridinium depressum (Pyrophyceae) with 101 individuals $/ \mathrm{L}(1.94 \%$ of the total phytoplankton abundance). Other common tolerant species include Anabaena affins (Cyanophyceae), Euglena candata, Phacus longicanda (Euglenophyceae), Amphoria ovaris, Synedra affins (Bacillariophyceae), and Pediastrum simplex (Chlorophyceae). Phytoplankton species have been used as indicators of organic pollution [4][56][57]. Some of the taxa recorded like Euglena, Ceratium, Peridinium, Anabaena, Closterium, Scenedesmus, and Pediastrum were indicative of eutrophic condition [56].

Spatially, station 3 recorded the most abundant individuals $(1108$ individuals/ $\mathrm{L}$ or $21.3 \%$ ), followed by station 2 (1007individuals/L or $19.3 \%$ ) while station 1 (748 individuals/L or $14.3 \%$ ) was the least. One-way ANOVA showed that stations 2 and 3 were significantly $(\mathrm{F}=10.3$, $p<0.05$ ) higher than stations $1,4-6$ in terms of 
abundance. Stations 2 and 3 had the highest number of individuals despite their high velocities; this could be due to little or human activities in the stations. Stations 1, $4-6$ were significantly lower with station 1 being the lowest. Stations $4-6$ were subjected to intense sand mining activities. Sand mining adversely affects both physical and biological environments, often extending beyond the mining sites [28]. Apart from constant agitation of the water, it increases turbidity levels and reduces light penetration which hinders the photosynthetic activity, productivity, and growth of phytoplankton [58].

The low abundance recorded in station 1 could be attributed to perturbation from the large number of children swimming in the station. This was observed throughout the dry season sampling period, which also reflected in the levels of some physicochemical parameters. The effect of increased runoffs from the rains also could be responsible during the wet season. Plankton abundance usually decreases as the amount of rainfall increase; attributed to high turbidity and high flow velocity [4][48][56]. The highest and lowest abundance were recorded among the Chlorophyceae and Pyrrophyceae respectively. Among the Chlorophyceae, station 4 (212 individuals/l) was significantly $(\mathrm{F}=11.34$; $p<0.05$ ) lower than station 3. (431 individual/1) while among the Pyrrophyceae, the downstream stations recorded relatively lower abundance. Also, among the Cyanophyceae, the relatively unperturbed upstream stations (2 and 3 ) were significantly $(\mathrm{F}=4.33, \quad p<0.05)$ higher than the perturbed stations $(1,4-5)$ while station 6 showed signs of recovery. A significant increase in the number of species and individuals of biota after dredging operations [62].

\subsection{Phytoplankton Community Structure}

Diversity indices have an important application in plankton studies especially in relation to the assessment of pollution and waterbody productivity [59]. In aquatic communities, it is a general knowledge that species diversity and richness tend to decrease with increasing perturbation; though some tolerant species usually break out [60]. The phytoplankton groups responded differently to the effects of anthropogenic activities which reflected in their community structures (Table 3 ). Perturbations in water columns caused by sand-mining activities exert selective effects on the aquatic biota [54][61]. Chlorophyceae and Pyrrophyceae had the highest and lowest Shannon-Wiener diversity index $(\mathrm{H})$ respectively. Among the Chlorophyceae, station 3 had the highest value (2.469) and station 1, the lowest (2.261), followed by station 4 (2.441).

The downstream stations $(4-6)$ had relatively lower Shannon-Wiener diversity index among Pyrrophyceae. These values indicated some level of perturbation attributed to sand mining. [63] classified water bodies with Shannon-Wiener diversity Index as clean ( $>4.5)$, slight pollution (4.53 ), moderate pollution (3-2), heavy pollution (2-1), and high pollution $(<1)$. Margalef index is an indicator of community richness in aquatic and terrestrial ecosystems [64]. Margalef Species Richness followed the same trend as ShannonWiener Diversity Index $(\mathrm{H})$ among the phytoplankton groups; though the spatial variations were different. Among the Chlorophyceae, station 4 had the highest value (2.054), followed by station 1 (2.029) while the relatively unperturbed stations 3 (1.813) and 2 (1.871) were lower. The perturbed downstream stations $(4-6)$ had relatively higher Margalef Species Richness among Pyrrophyceae. This is because the Margalef index focuses on the richness and taxonomic composition rather than community abundance [65]. Evenness index indicates the degree to which species are equally distributed in a community; low values indicate that one or a few species dominate while high values indicate the relatively equal distribution of each species [66]. The evenness values were generally higher among the upstream stations $(1-3)$ except Chlorophyceae (0.7997) in station 1 while Bacillariophyceae (0.9779) and Chlorophyceae $(0.9830)$ were relatively higher in station 5. Evenness index values were close to 1 indicating that the species were distributed evenly in most of the stations. The lower value recorded in Chlorophyceae in station 1 could be attributed to effect children swimming and season. The dominance of Bacillariophyceae and Chlorophyceae in station 5 is an indication of eutrophication [67]. Bacillariophyceae has high tolerance to chemicals and nutrients [68]. 
Table 2: Species Composition, Abundance and Distribution of Phytoplankton in Eme River, Umuahia, Nigeria

\begin{tabular}{|c|c|c|c|c|c|c|c|c|c|}
\hline Group & Taxa & $\begin{array}{c}\text { Station } \\
1\end{array}$ & $\begin{array}{l}\text { Station } \\
2\end{array}$ & $\begin{array}{l}\text { Station } \\
3\end{array}$ & $\begin{array}{c}\text { Station } \\
4\end{array}$ & $\begin{array}{l}\text { Station } \\
5\end{array}$ & $\begin{array}{l}\text { Station } \\
6\end{array}$ & Total & $\begin{array}{l}\text { RA } \\
(\%)\end{array}$ \\
\hline \multirow[t]{6}{*}{ Cyanophyceae } & Anabaena affins & 14 & 29 & 26 & 30 & 36 & 35 & 170 & 3.26 \\
\hline & A. spiroides & 12 & 36 & 31 & 14 & 21 & 19 & 133 & 2.55 \\
\hline & $\begin{array}{l}\text { Oscilatoria } \\
\text { laccustris }\end{array}$ & 14 & 21 & 35 & 21 & 30 & 30 & 151 & 2.90 \\
\hline & $\begin{array}{l}\text { Spirulina } \\
\text { substilissinia }\end{array}$ & 18 & 24 & 29 & 26 & 14 & 14 & 125 & 2.40 \\
\hline & $\begin{array}{l}\text { Microcystis } \\
\text { weswenbergii }\end{array}$ & 11 & 23 & 24 & 25 & 18 & 32 & 133 & 2.55 \\
\hline & $\begin{array}{l}\text { Coelosphaerium } \\
\text { pallidum }\end{array}$ & 10 & 27 & 20 & 24 & 22 & 23 & 126 & 2.41 \\
\hline \multirow[t]{6}{*}{ Euglenophyceae } & Euglena candata & 13 & 35 & 20 & 15 & 42 & 32 & 157 & 3.01 \\
\hline & E. acus & 20 & 24 & 25 & 15 & 12 & 34 & 130 & 2.59 \\
\hline & E. proxima & 27 & 20 & 28 & 25 & 26 & 12 & 138 & 2.65 \\
\hline & $\begin{array}{l}\text { Phacus } \\
\text { longicanda }\end{array}$ & 23 & 29 & 37 & 31 & 20 & 19 & 159 & 3.05 \\
\hline & P. caudata & 24 & 30 & 23 & 15 & 24 & 10 & 126 & 2.42 \\
\hline & $\begin{array}{l}\text { Trachelomonas } \\
\text { aramata }\end{array}$ & 33 & 14 & 30 & 20 & 28 & 0 & 125 & 2.40 \\
\hline \multirow{8}{*}{ Bacillariophyceae } & Amphoria ovaris & 24 & 28 & 32 & 40 & 21 & 16 & 161 & 3.09 \\
\hline & $\begin{array}{l}\text { Melosira } \\
\text { granulata }\end{array}$ & 25 & 30 & 32 & 42 & 22 & 39 & 190 & 3.64 \\
\hline & $M$ varians & 25 & 29 & 23 & 15 & 19 & 20 & 131 & 2.51 \\
\hline & Synedra acus & 32 & 28 & 23 & 19 & 19 & 13 & 134 & 2.57 \\
\hline & S. ulna & 25 & 29 & 19 & 35 & 18 & 25 & 151 & 2.90 \\
\hline & S. affins & 20 & 31 & 28 & 39 & 28 & 30 & 176 & 3.38 \\
\hline & $\begin{array}{l}\text { Cyclotella } \\
\text { glomerata }\end{array}$ & 33 & 30 & 27 & 23 & 20 & 13 & 146 & 2.80 \\
\hline & $\begin{array}{l}\text { Tragilaria } \\
\text { crotonesis }\end{array}$ & 15 & 22 & 32 & 21 & 33 & 22 & 145 & 2.78 \\
\hline \multirow[t]{12}{*}{ Chlorophyceae } & $\begin{array}{l}\text { Pediastrum } \\
\text { clathratum }\end{array}$ & 19 & 27 & 28 & 31 & 20 & 20 & 145 & 2.78 \\
\hline & P. simplex & 26 & 21 & 43 & 15 & 24 & 31 & 160 & 3.07 \\
\hline & P. dublex & 4 & 39 & 28 & 21 & 26 & 27 & 145 & 2.78 \\
\hline & $\begin{array}{l}\text { Closterium } \\
\text { moniliferum }\end{array}$ & 31 & 32 & 38 & 17 & 14 & 21 & 153 & 2.93 \\
\hline & C. parvulum & 20 & 26 & 29 & 22 & 22 & 21 & 140 & 2.69 \\
\hline & C. macilentum & 1 & 25 & 34 & 16 & 19 & 23 & 118 & 2.26 \\
\hline & $\begin{array}{l}\text { Cosmarium } \\
\text { amoerum }\end{array}$ & 2 & 29 & 42 & 11 & 30 & 25 & 139 & 2.67 \\
\hline & $\begin{array}{l}\text { Mougeotia } \\
\text { scalaris }\end{array}$ & 32 & 29 & 34 & 17 & 18 & 16 & 146 & 2.80 \\
\hline & Volvox aureus & 26 & 21 & 38 & 17 & 22 & 30 & 154 & 2.95 \\
\hline & $\begin{array}{l}\text { Chlamydomonas } \\
\text { Atactogam }\end{array}$ & 26 & 31 & 40 & 9 & 21 & 16 & 143 & 2.74 \\
\hline & $\begin{array}{l}\text { Planktosphaeria } \\
\text { Gelatinosa }\end{array}$ & 28 & 43 & 48 & 19 & 24 & 18 & 180 & 3.45 \\
\hline & $\begin{array}{l}\text { Scenedesmus } \\
\text { quardriacauda }\end{array}$ & 11 & 34 & 29 & 17 & 26 & 36 & 153 & 2.93 \\
\hline \multirow[t]{5}{*}{ Pyrophyceae } & $\begin{array}{l}\text { Ceratium } \\
\text { candelabum }\end{array}$ & 30 & 31 & 45 & 16 & 6 & 19 & 147 & 2.82 \\
\hline & C. hirudenella & 23 & 29 & 34 & 25 & 9 & 25 & 145 & 2.78 \\
\hline & $\begin{array}{l}\text { Peridinium } \\
\text { depressum }\end{array}$ & 23 & 18 & 31 & 8 & 9 & 12 & 101 & 1.94 \\
\hline & P. latum & 28 & 33 & 23 & 25 & 20 & 8 & 137 & 2.63 \\
\hline & Total & 748 & 1007 & 1108 & 781 & 783 & 786 & 5213 & \\
\hline
\end{tabular}


Table 3: Community Structures of Phytoplankton in Eme River, Umuahia, Nigeria.

\begin{tabular}{|c|c|c|c|c|c|c|c|}
\hline Group & $\begin{array}{l}\text { Biodiversity } \\
\text { Indices }\end{array}$ & $\begin{array}{c}\text { Station } \\
1 \\
\end{array}$ & $\begin{array}{c}\text { Station } \\
2 \\
\end{array}$ & $\begin{array}{c}\text { Station } \\
3 \\
\end{array}$ & $\begin{array}{c}\text { Station } \\
4\end{array}$ & $\begin{array}{c}\text { Station } \\
5\end{array}$ & $\begin{array}{c}\text { Station } \\
6 \\
\end{array}$ \\
\hline \multirow[t]{4}{*}{ Cyanophyceae } & Individuals & $79^{b}$ & $160^{\mathrm{a}}$ & $165^{\mathrm{a}}$ & $140^{\mathrm{b}}$ & $141^{\mathrm{b}}$ & $153^{\mathrm{a}}$ \\
\hline & Shannon-Wiener $(\mathrm{H})$ & 1.773 & 1.775 & 1.776 & 1.768 & 1.743 & 1.747 \\
\hline & Evenness (E) & 0.9811 & 0.9837 & 0.9844 & 0.9761 & 0.9528 & 0.9561 \\
\hline & Margalef (D) & 1.144 & 0.9852 & 0.9793 & 1.012 & 1.01 & 0.9939 \\
\hline \multirow[t]{4}{*}{ Euglenophyceae } & Individuals & 140 & 152 & 163 & 121 & 152 & 107 \\
\hline & Shannon-Wiener $(\mathrm{H})$ & 1.756 & 1.752 & 1.772 & 1.749 & 1.728 & 1.499 \\
\hline & Evenness (E) & 0.9647 & 0.9614 & 0.9804 & 0.9578 & 0.9381 & 0.8955 \\
\hline & Margalef (D) & 1.012 & 0.9952 & 0.9816 & 1.043 & 0.9952 & 0.856 \\
\hline \multirow[t]{4}{*}{ Bacillariophyceae } & Individuals & 199 & 227 & 216 & 234 & 180 & 178 \\
\hline & Shannon-Wiener $(\mathrm{H})$ & 2.055 & 2.075 & 2.064 & 2.017 & 2.057 & 2.011 \\
\hline & Evenness (E) & 0.9754 & 0.9956 & 0.9849 & 0.9399 & 0.9779 & 0.9341 \\
\hline & Margalef (D) & 1.322 & 1.29 & 1.302 & 1.283 & 1.348 & 1.351 \\
\hline \multirow[t]{4}{*}{ Chlorophyceae } & Individuals & $226^{\mathrm{a}}$ & $357^{\mathrm{bc}}$ & $431^{b}$ & $212^{\mathrm{a}}$ & $266^{\mathrm{ac}}$ & $284^{\mathrm{ac}}$ \\
\hline & Shannon-Wiener $(\mathrm{H})$ & 2.261 & 2.463 & 2.469 & 2.441 & 2.468 & 2.453 \\
\hline & Evenness (E) & 0.7997 & 0.9779 & 0.9845 & 0.9569 & 0.983 & 0.9688 \\
\hline & Margalef (D) & 2.029 & 1.871 & 1.813 & 2.054 & 1.97 & 1.947 \\
\hline \multirow[t]{4}{*}{ Pyrrophyceae } & Individuals & 104 & 111 & 133 & 74 & 44 & 64 \\
\hline & Shannon-Wiener $(\mathrm{H})$ & 1.379 & 1.363 & 1.358 & 1.305 & 1.279 & 1.302 \\
\hline & Evenness (E) & 0.993 & 0.9765 & 0.9724 & 0.9218 & 0.8985 & 0.9187 \\
\hline & Margalef (D) & 0.6459 & 0.637 & 0.6135 & 0.697 & 0.7928 & 0.7213 \\
\hline
\end{tabular}

Remarks: $a, b, c=$ Abundance (Individuals/l) with different superscripts across the rows are significantly different $(\mathrm{p}<0.05)$.

The relationships between phytoplankton and environmental variables were determined by using Canonical Correspondence Analysis (CCA). The importance of the variable was indicated by the length of the arrow and shows positive or negative correlations with the axis [69-70]. The analysis showed that electrical conductivity and phosphate exerted a greater positive influence on the relative abundance of the phytoplankton groups compared to the higher negative influence exerted by $\mathrm{pH}$ and temperature (Figure. 2).

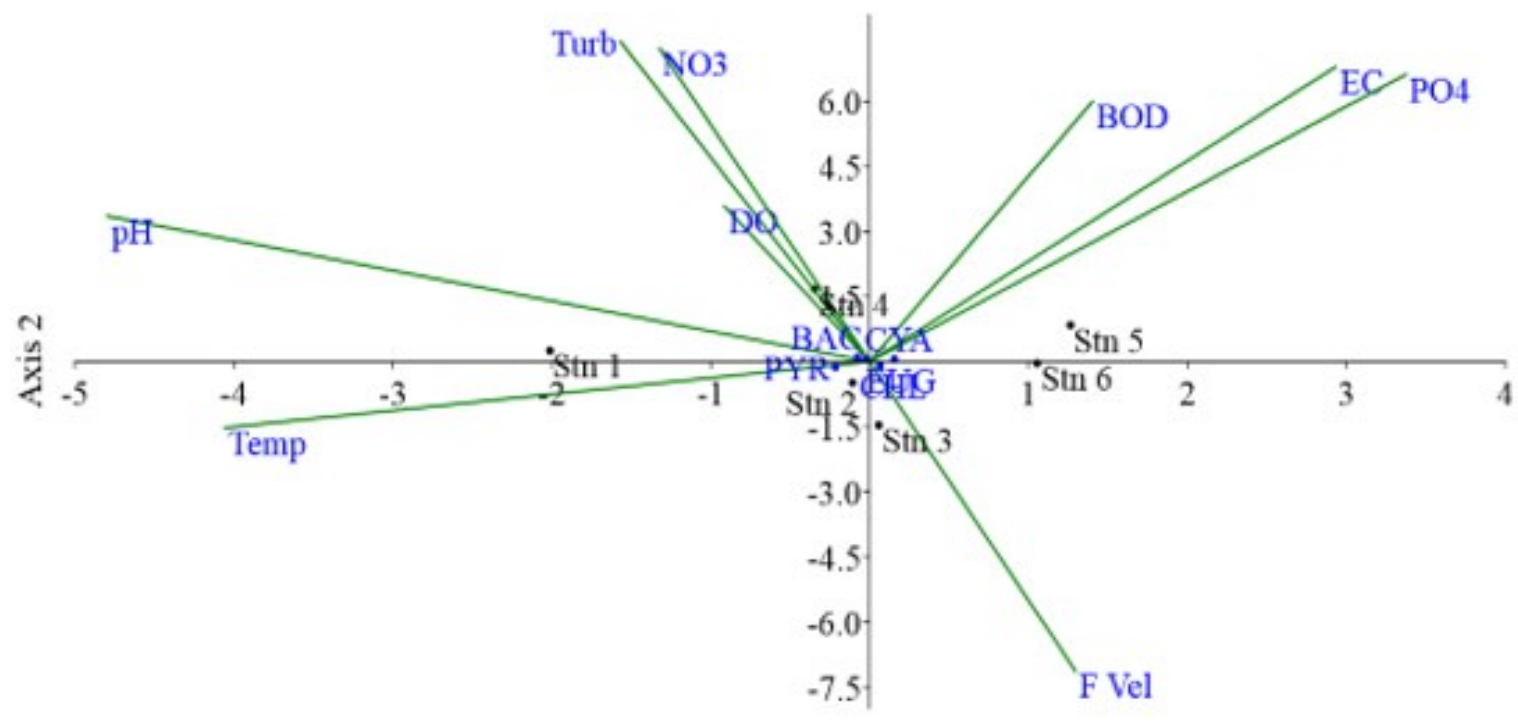

Axis 1

Figure. 2: Canonical Correspondence Analysis (CCA) Ordination Showing Relationships between Phytoplankton Groups, Stations and Environmental Variables (BOD - biochemical oxygen demand, DO dissolved oxygen, Turb - turbidity, Temp - water temperature, $\mathrm{NO}_{3}$ - nitrates, $\mathrm{PO}_{4}$ - phosphates, $\mathrm{EC}-$ electrical conductivity, FVel - flow velocity, CYA - cyanophyceae, BAC - bacillariophyceae, CHL chlorophyceae, EUG - euglenophyceae and PYR - Pyrrophyceae)

Biochemical oxygen demand, electrical conductivity, and phosphate exerted positive influence on cyanophyceae and flow velocity on euglenophyceae and Chlorophyceae. On the other hand, turbidity and nitrate exerted negative influence on Bacillariophyceae and temperature on 
Pyrrophyceae. Spatially, $\mathrm{pH}$ and flow velocity exerted negative influence respectively in stations 1 and 3 while turbidity and nitrate exerted negative influence in station 4.

\section{Conclusion}

The water quality and phytoplankton structure showed that the water was tending towards eutrophication. This is attributed to the observed anthropogenic activities and cumulative impacts of all the activities in the watershed. The impact of sand mining activities was observed more in the downstream stations $(4-6)$ while perturbation from swimming children and related activities was observed in station 1. The community E. D. Anyanwu, M. C. Okorie, and Odo S. N, "Macroinvertebrates as bioindicators of Water Quality of Effluent-receiving Ossah River, Umuahia, Southeast Nigeria," Zanco Journal of structure reflected the impacts of the activities while CCA identified the major water quality parameters that influenced the phytoplankton community structure. There is need to regulate sand mining activities due to its negative impact on the biota.

\section{References}

[1] D. Bordoloi and P. P. Baruah, "Water quality assessment using phytoplankton in a historical pond of Upper Assam," Journal of Algal Biomass and Utilisation, vol.5, no. 2, pp. $1-7$. 2012.

[2] E. B. Amah-Jerry, E. D. Anyanwu, and D. A. Avoaja, "Anthropogenic impacts on the water quality of Aba River, Southeast Nigeria," Ethiopian Journal of Environmental Studies and Management, vol.10, no. 3, pp. 299-314. 2017. doi: 10.4314/ejesm.v10i3.3

[3] J. R. Karr, J. D. Allen, and A. C. Benke, "River conservation in the United States and Canada," in: Global perspectives on River conservation, P. J. Boon, B. R. Davies, and G. E. Petts, Eds., New York, NY, USA: Wiley, 2000, pp. 3-39.

[4] G. N. Nwonumara, "Water Quality and Phytoplankton as Indicators of Pollution in a Tropical River," in Proceedings of 6th NSCB Biodiversity Conference, University of Uyo, Uyo, Nigeria, 2018, pp. $83-89$.

[5] F. Patang, A. Soegianto, and S. Hariyanto, "Benthic Macroinvertebrates Diversity as Bioindicator of Water Quality of Some Rivers in East Kalimantan, Indonesia," International Journal of Ecology, 2018. doi $: 10.1155 / 2018 / 5129421$
[6] E. D. Anyanwu, M. C. Okorie, and Odo S. N, "Macroinvertebrates as bioindicators of Water Quality of Effluent-receiving Ossah River, Umuahia, Southeast Nigeria," Zanco Journal of Pure and Applied Sciences, vol. 31, no. 5, pp. 917. 2019. doi: 10.21271/ZJPAS.31.5.2

[7] O. O. Aliu, E. O. Akindele, and I. F. Adeniyi, "Biological assessment of the Headwater Rivers of Opa Reservoir, Ile-Ife, Nigeria, using ecological methods," The Journal of Basic and Applied Zoology, vol. 81, no. 11. 2020. doi: 10.1186/s41936-020-00151-5

[8] R. J. Geider, et al., "Primary productivity of planet earth: Biological determinants and physical constraints in terrestrial and aquatic habitats," Global Change Biology, vol. 7, no. 8, pp. 849-882. 2001. doi:10.1046/j.13652486.200100448.x

[9] N. Anyinkeng, A. M. Mih, T. A. Suh, and C. C. Awah, "Phytoplankton diversity and abundance in water bodies as affected by anthropogenic activities within the Buea municipality, Cameroon," Journal of Ecology and the Natural Environment, vol. 8, no. 7, pp.99-114. 2016. doi: 10.5897/JENE2016.0566

[10] E. Bellinger and D Sigee, "A Key to the More Frequently Occurring Freshwater Algae," In: Freshwater Algae: Identification, Enumeration and Use as Bioindicators (2nd Edition)", WileyBlackwell, pp. 141 -251. 2015.

[11] Z. H. Yusuf, "Phytoplankton as bioindicators of water quality in Nasarawa reservoir, Katsina State Nigeria," Acta Limnologica Brasiliensia, vol. 32, e4. 2020. doi : 10.1590/S2179-975X3319

[12] T. K. Parmar, D. Rawtani, and Y. Agrawal, "Bioindicators: The natural indicator of environmental pollution," Journal of Frontiers in Life Sciences, vol. 9, no. 11, pp. 110 - 118. 2016.

[13] B. E. Hatt, T. D. Fletcher, C. J. Walsh and S. L. Taylor, "The influence of urban density and drainage infrastructure on the concentrations and loads of pollutants in small streams," Environmental Management, vol. 34, no. 1, pp. 112-124. 2004. doi:10.1007/s00267-004-0221-8

[14] J. Heino, "The importance of metacommunity ecology for environmental assessment research in the freshwater realm," Biological Reviews, vol. 88, no. 1, pp. 166-178. 2013. doi:10.1111/j.1469185X.2012.00244.X

[15] P. Znachor, et al., "Changing environmental conditions underpin long-term patterns of phytoplankton in a freshwater reservoir," Science of the Total Environment, vol. 710, 2020. doi:10.1016/j.scitotenv.2019.135626 
[16] APHA, "Standard Methods for the Analysis of Water and Wastewater, 22nd Edition," American Public Health Association, Washington D.C. 2012. pp. 2671.

[17] S. Janse van Vuuren, J. Taylor, A. Gerber, and C. van Ginkel, "Easy identification of the most common freshwater algae. A guide for the identification of microscopic algae in South African freshwaters," Resource Quality Services RQS, 2006. pp. 212.

[18] J. Park, K. Kim, C. Cho, M. Kang, and B. Kim, "Spatio-temporal characteristics of air and water temperature change in the middle reach of the Nakdong River," Journal of Environmental Policy and Administration, vol. 9, pp. 233-253. 2016.

[19] S. J. Dugdale, R. Allen Curry, A. St-Hilaire and S. N. Andrews, "Impact of future climate change on water temperature and thermal habitat for keystone fishes in the Lower Saint John River," Water Resources Management, vol. 32, no. 15, pp. 4853-4878. 2018.

[20] D. Chapman and V. Kimstach, "Chapter 3, Selection of Water Quality Variables," in: Water Quality Assessment. A Guide to the use of Biota, Sediments and Water in Environmental Monitoring (2nd Edition), D. Chapman, ed. London UK and New York USA: Taylor and Francis, 1996, pp. 609.

[21] E. D. Anyanwu, R. B. Ikomi, and F. O. Arimoro, "Water quality and zooplankton of the Ogba River, Benin City, Nigeria," African Journal of Aquatic Science, vol. 38, no. 2, 193-199. 2013.

[22] S. Verma, D. Tiwari, and A. Verma, "Algal dynamics of River Pandu in relation to ambient environment," Ecoprint, vol. 20, pp. 9-17. 2013.

[23] A. O. Ekwu and N. D. Udo, "Plankton Communities of Ikpa River, Southeast Nigeria Exposed to Sanddredging Activities," Journal of Fisheries and Aquatic Science, vol. 9, no. 5, pp. 345 -351. 2014.

[24] T. P. Yen and H. Rohasliney, "Status of Water Quality Subject to Sand Mining in the Kelantan River, Kelantan," Tropical Life Sciences Research, vol. 24, no. 1, pp. 19-34. 2013.

[25] E. D. Anyanwu and S. N. Umeham, "Identification of waterbody status in Nigeria using predictive index assessment tools: a case study of Eme River, Umuahia, Nigeria," International Journal of Energy and Water Resources, vol. 4, no. 3, pp. 271-279. 2020. doi : 10.1007/s42108-020-00066-5

[26] M. A. Ashraf, M. J. Maah, I. Yusoff, A. Wajid, and K. Mahmood, "Sand mining effects, causes and concerns: A case study from Bestari Jaya, Selangor, Peninsular Malaysia," Scientific Research and Essays, vol. 6, no. 6, pp. 1216-1231. 2011.

[27] E. Seiyaboh, E. N. Ogamba, and D. I. Utibe, "Impact of dredging on the water quality of Igbedi Creek, Upper Nun River, Niger Delta, Nigeria," IOSR
Journal Of Environmental Science, Toxicology and Food Technology, vol. 7, no. 5, pp. 51-56. 2013.

[28] S. Sheeba, "Biotic environment and sand mining - A case study from Ithikkara River, South West Coast of India," Journal of Industrial Pollution Control, vol. 25, no. 2, pp. 133-138. 2009.

[29] V. S. Kale, "Consequence of temperature, pH, turbidity and dissolved oxygen water quality parameters," International Advanced Research Journal in Science, Engineering and Technology, vol. 3, no. 8, pp. 186-190. 2016.

[30] E. D. Anyanwu and C. S. Emeka, "Application of water quality index in the drinking water quality assessment of a southeastern Nigeria river," Food and Environment Safety, vol. XVIII, no. 4, pp. 308 314. 2020.

[31] J. A. Akankali, A. S. Idongesit, and P. E. Akpan, "Effects of sand mining activities on water quality of Okoro Nsit stream, Nsit Atai Local Government Area, Akwa Ibom State, Nigeria," International Journal of Development and Sustainability, vol. 6, pp. 451-462. 2017.

[32] E. D. Anyanwu and A. B. Ukaegbu, "Index approach to water quality assessment of a south eastern Nigerian river," International Journal of Fisheries and Aquatic Studies, vol. 7, no. 1, pp. 153-159. 2019.

[33] M. Rehman, et al., "Dredging induced changes in zooplankton community and water quality in Dal Lake, Kashmir, India," African Journal of Environmental Science and Technology, vol. 10, no. 5, pp. 141-149. $2016 . \quad$ doi: 10.5897/AJEST2016.2096

[34] Z. Dorak, "Zooplankton abundance in the lower Sakarya River Basin (Turkey): Impact of environmental variables," Journal of Black Sea/Mediterranean Environment, vol. 19 no.1, pp. 122. 2013.

[35] FMEnv. 2011. National Environmental (Surface and Groundwater Quality Control) Regulations, S.I. No. 22, Gazette no. 49, vol. 98. Abuja: Federal Ministry of Environment.

[36] A. S. Rao, S. Marshall, J. Gubbi, M. Palaniswami, R. Sinnott, and V. Pettigrove, "Design of Low-Cost Autonomous Water Quality Monitoring System," International Conference on Advances in Computing, Communications and Informatics (ICACCI), Mysore, 22-25, August 2013, pp. 14-19.

[37] H. Aydin, F. Ustaoğlu, Y. Tepe, and E. N Soylu, "Assessment of water quality of streams in northeast Turkey by water quality index and multiple statistical methods," Environmental Forensics, vol. 22, pp. 280-287. 2020.2 doi: $10.1080 / 15275922.2020 .1836074$. 
[38] A. Bhatnagar, S. N. Jana, S. K. Garg, B. C. Patra, G. Singh, and U. K. Barman, "Water quality management in Aquaculture", In: Course Manual of summer school on development of sustainable Aquaculture technology in fresh and saline water. CCS Hagyana Agricultural, Hisar (India), 3, 2004. pp. 203-210.

[39] A. M. Al-Sulaiman and B. H. Khudair, "Correlation between BOD5 and COD for Al-Diwaniyah Wastewater Treatment Plants to obtain the Biodegradability Indices," Pakistan Journal of Biotechnology, vol. 15, no. 2, pp. 423-427. 2018.

[40] R.K. Patel, "Nitrates-its generation and impact on environment from mines: A Review," National Conference on Sustainable Mining Practice, India. Dec. 2016, pp. $2-3$.

[41] Lehigh Environmental Initiative, "Nitrates," Enviro. Sci. Inquiry. http://www.ei.lehigh.edu/envirosci/watershed/w q/wqbackground/nitratesbg.html. Accessed 17 March 2021.

[42] V. G. Christensen, K. E. Lee, J. M. McLees, and S. L. Niemela, "Relations between retired agricultural land, water quality, and aquatic-community health, Minnesota River basin," Journal of Environmental Quality, vol. 41, pp. 1459-1472. 2011.

[43] V. K. Dubey, U. K. Sarkar, R. S. Kumar, J. I. Mir, A. Pandey, and W. S. Lakra, "Length-weight relationships (LWRs) of 12 Indian freshwater fish species from an un-impacted tropical river of Central India (River Ken)," Journal of Applied Ichthyology, vol. 28, pp. 854-856. 2012.

[44] R. M. Kutama, M. M. Abubakar, and M. L. Balarabe, "The plankton as indicators of water quality in Kusalla Reservoir: A shallow man made lake," IOSR Journal of Pharmacy and Biological Sciences, vol. 9, no. 3, pp. 12-15. 2014.

[45] A. D. Kshirsagar, M. L. Ahire, and V. R. Gunale, "Phytoplankton Diversity Related to Pollution from Mula River at Pune City," Terrestrial and Aquatic Environmental Toxicology, vol. 6, no. 2, pp. 136-142. 2012.

[46] M. N. Bwala, "The abundance of phytoplankton in River Nggada and River Ngadda-Bul, Maiduguri Metropolis, Borno State, Nigeria," Global Educational Research Journal, vol. 7, no. 7, pp. 820829. 2019.

[47] I. E. Ekpo, M. A. Essien-Ibok, and A. O. Duncan, "Densities, spatial distribution and community structure of plankton of Odot Stream," Journal of Ecology and the Natural Environment, vol. 7, no. 6, pp. 180-187. 2015. doi:10.5897/JENE2015.0521

[48] F. O. Arimoro, H. E. Olisa, U. N. Keke, A.V Ayanwale, and V. I. Chukwuemeka, "Exploring spatio-temporal patterns of plankton diversity and community structure as correlates of water quality in a tropical stream," Acta Ecologica Sinica, vol. 38, pp. 216-223. 2018.

[49] O. A. Davies, B. B. Otene, D. Amachree, and F. A. Nwose, "Phytoplankton Community of Upper Reaches of Orashi River, Rivers State, Nigeria," Specialty Journal of Biological Sciences, vol. 5, no. 3, pp. 1-12. 2019.

[50] T. Rajagopal, A. Thangamani, and G. Archunan, "Comparison of physico-chemical parameters and phytoplankton species diversity of two perennial ponds in Sattur area, Tamil Nadu," Journal of Environmental Biology, vol. 31, pp. 787-794. 2010.

[51] G. M. N. Rao and P. M. Pragada, "Seasonal abundance of micro algae in Pandi Back waters of Godavari Estuary, Andra Pradesh, India," Notulae Scientia Biologicae, vol. 2, pp. 26-29. 2010.

[52] P. Verma, U. C. Gupta, P. R. Adiyecha, and H.A. Solanki, "Seasonal variation in the phytoplankton biodiversity of Chandlodia Lake," International Journal of Innovative Research in Science, Engineering and Technology, vol. 3, no. 1, pp. 1-6. 2014.

[53] B. O. Dimowo, "The phytoplankton species composition and abundance of Ogun River, Abeokuta, Southwestern Nigeria," International Journal of Aquaculture, vol. 3, no. 2, pp. 4-7. 2013. doi: 10.5376/ija.2013.03.0002

[54] M. A. Essien-Ibok, "The phytoplankton community structure of a tropical river in Niger Delta, Nigeria", Journal of Environment and Earth Science, vol. 3, no. 8, pp. $76-81.2013$.

[55] C. M. Palmer,"A composite rating of algae tolerating organic pollution," Journal of Phycology, vol. 5, pp. 78-82. 1969.

[56] O. I. Okogwu and A. O. Ugwumba, "Seasonal dynamics of phytoplankton in two tropical rivers of varying size and human impact in Southeast Nigeria", Revista De Biología Tropical, vol. 61, no. 4, pp. 1827-1840. 2013.

[57] Z. Salem, M. Ghobara, and A. A. El Nahrawy, "Spatio-temporal evaluation of the surface water quality in the middle Nile Delta using Palmer's algal pollution index", Egyptian Journal of Basic and Applied Sciences, vol. 4, pp. 219-226. 2017. doi:10.1016/j.ejbas.2017.05.003

[58] Y. Tanimu, S. P. Bako, J. A. Adakole, and J. Tanimu, "Phytoplankton as bioindicators of water quality in Saminaka reservoir, Northern Nigeria," Proceedings of the 2011 International Symposium on Environmental Science and Technology, Dongguan, Guangdong Province, China. 2011.pp. 318-322. 
[59] A. W. Hastuti, Y. Pancawati, and I. N. Surana, "The abundance and spatial distribution of plankton communities in Perancak Estuary, Bali", IOP Conference Series: Earth and Environmental Science, Volume 176, 2nd International Conference on Marine Science: Better Insight for the Healthy Ocean, 6-7 September 2017, Bogor, Indonesia. 2018. doi :10.1088/1755-1315/176/1/012042

[60] M. Q. Xu, H. Cao, P. Xie, D. G. Deng, W. S. Feng, and $\mathrm{J} . \mathrm{Xu}$, "The temporal and spatial distribution, composition and abundance of planktonic protozoa, with special relation to eutrophication in the Chaohu Lake, China," European Journal of Protistology, vol. 41, pp. 183-192. 2005.

[61] L. Koehnken, M. S. Rintoul, M. Goichot, D. Tickner, A-C. Loftus, and M.C. Acreman, "Impacts of riverine sand mining on freshwater ecosystems: A review of the scientific evidence and guidance for future research," River Research and Applications, vol. 36, no. 3, pp. 325-326. 2020. doi: 10.1002/rra.3586.

[62] E. J. Ko, D. K. Kim, E. S. Jung, Y. J. Heo, G. J. Joo, and H. W. Kim, "Comparison of Zooplankton Community Patterns in Relation to Sediment Disturbances by Dredging in the Guemho River, Korea," Water, vol. 12, pp. 3434. 2020. doi:10.3390/w12123434.

[63] B. H. Zheng, Z. Q. Tian, L. Zhang, and F.D. Zheng, "The characteristics of the hydrobios' distribution and the analysis of water quality along the west shore of Taihu Lake," Acta Ecologica Sinica, vol. 27, pp. 4214-4223. 2007.

[64] B. Yang, Y. Jiang, W. He, W. Liu, X. Kong, S.E. Jørgensen, and $\mathrm{F}$. Xu, "The tempo-spatial variations of phytoplankton diversities and their correlation with trophic state levels in a large eutrophic Chinese lake," Ecological Indicators, vol. 66, pp. 153-162. 2016. doi: 10.1016/j.ecolind.2016.01.013.

[65] F. Meng, Z. Li, L. Li, F. Lu, Y. Liu, X. Lu, and Y. Fan, "Phytoplankton alpha diversity indices response the trophic state variation in hydrologically connected aquatic habitats in the Harbin Section of the Songhua River," Scientific Reports, vol. 10, no.1, pp. 1-13. 2020. doi: 10.1038/s41598-020-78300-7.

[66] E. K. Morris, et al., "Choosing and using diversity indices: insights for ecological applications from the German Biodiversity Exploratories," Ecology and Evolution, vol. 4, no. 18, pp. 3514-3524. 2014. doi: 10.1002/ece3.1155

[67] B. A. Fonge, P. T. Tabot, C. A. Mange, and C. Mumbang, "Phytoplankton community structure and physico-chemical characteristics of streams flowing through an agro- plantation complex in Tiko, Cameroon," Journal of Ecology and the NaturalEnvironment, vol. 7, no. 5, pp. 170-179. 2015. doi: 10.5897/JENE2015.0515

[68] A. Celekli and O. Kulkoyluoglu, "On the relationship between ecology and phytoplankton composition in a karstic spring (Cepni, Bolu)", Ecological Indicator, vol. 7, no. 2, pp. 497-503. 2007. doi : 10.1016/j.ecolind.2006.02.006

[69] N. Abrantes, S. C. Antunes, M. J. Pereira, and F. Goncalves, "Seasonal succession of cladocerans and phytoplankton and their interactions in a shallow eutrophic lake (Lake Vela, Portugal)," Acta Oecologica, vol. 29, no.1, pp. 54-64. 2006.

[70] C. Liu, L. Liu, and H. Shen, "Seasonal variations of phytoplankton community structure in relation to physico-chemical factors in Lake Baiyangdian, China," Procedia Environmental Sciences, vol. 2, pp. 1622-1631. 2010. 